\title{
The Effect of Problem Based Learning to Critical Thinking Ability of M1 Students in Plant Biotechnology Materials
}

\author{
Iir Nur Choiriya ${ }^{1)}$, Erlia Narulita ${ }^{2)}$, Areerat Chuseng ${ }^{3)}$ \\ ${ }^{1,2}$ Faculty of Teacher Training and Education, University of Jember, Indonesia. \\ ${ }^{3}$ Biology Teacher of Hatyaiwittayalai Somboonkulkanya School, Thailand. \\ email: iirnur@gmail.com
}

\begin{abstract}
This study aimed to determine the effect of learning based on learning problems on students' critical thinking skills in plant biotechnology materials. This research is a quasiexperimental type using the design of "Post test and pretest, Non Equivalent Control Group Design" which consists of two experimental classes. The first experimental class used the Problem Based Learning learning model and the second class used a discussion learning model. Problem-based learning motivates students to learn independently to find information themselves from various sources, such as the environment, media and the internet. This learning trains students to think critically about contextual problems related to the material so as to improve students' cognitive abilities ranging from identifying problems, formulating hypotheses, analyzing problems, evaluating and concluding.
\end{abstract}

Keywords: Problem based learning, critical thinking.

\section{INTRODUCTION}

Problem-based learning has evolved significantly over the past several years. There are many different modalities and there is much diversity in the field. The Process of PBL: It is important to note that these students had graduated from a more traditional educational system wherein the teacher holds the power and students are asked to produce a graded product (Barber et al., 2015). This kind of learning will certainly lead to less meaningful learning. Less meaningful learning is more prioritizing rote than on understanding and deeds so that learning outcomes become less embedded in the mindset and patterns of learners' actions. Less significant learning affects the low motivation of learners. The low motivation to learn these learners can affect the learning process of learners, so that learners learn to be not optimal. This requires serious attention from teachers in order to implement more meaningful learning, so that science can be well educated to learners (Hidayat., et al 2018). According to Savin-Baden (2007) there are significant characteristics of PBL that include: 1) complex real world situations that have no one 'right' answer are the organizing focus for learning, 2) students work in teams to confront the problem, to identify learning gaps, and to develop viable solutions, 3) students gain new information through selfdirected learning, 4) staff act as facilitators, 5) problems lead to the development of clinical problem-solving capabilities.

Having known the level of critical thinking skills it can be done improving the learning process. Innovation of suggested learning methods is a learning method that uses a constructivism approach such as Problem-Based Learning (PBL). The underlying principle in PBL, which is one of the student-centered teaching methods in education, is the development of students' higher-order thinking skills (Ersoy, 2014). Based on the importance of developing critical in support practical ability by using connected problem solving and creating new ideas, it is necessary to assess the ability of critical and creative thinking of students. This study aims to develop a system that accommodates these needs (Dewanto, 2018). 
The students' thinking skills are important to be improved, in line with the discourse of improving the quality of education in accordance with learning objectives (Hadi $d k k, 2018$ ). The purpose or the success of a learning process is achieved when it meets three important criteria, namely the aspects of knowledge, attitude and skills. Critical thinking skills which are identical to independent learning style can be applied by using constructivist learning models, such as problem-based learning. Learning models with investigationactivities, such as inquiry, involve students fully in the teaching and learning activities either in groupor individual, which is one way to develop students' critical thinking skills. According of Sutama et al (2014), Sutarma et al state that there is an increasing trend in the students' critical thinking skills with the implementation of inquiry learning model.

One of the well-known contributors to the development of critical thinking is Robert H. Ennis in stating that critical thinking is reasonable reflective thinking that focuses on deciding what to believe or do. According to Ennis (1991: 20), there are six basic elements in critical thinking abbreviated to FRISCO, namely; 1) F (Focus), which focuses on questions or issues that are available to make a decision about what is believed, 2) R (Reason), which is to know the reasons that support or oppose decisions made based on relevant situations and facts, 3) I (Inference), which is to make reasonable or convincing conclusions. An important part of this conclusion is to identify assumptions and find solutions, considerations of the interpretation of the situation and evidence, 4) $S$ (Situation), which is understanding the situation and always keeping the situation in mind will help clarify the question and know the meaning of the relevant key parts as a support, 5) $\mathrm{C}$ (Clarity), which explains the meaning or terms used, 6) $\mathrm{O}$ (Overview), which is a review and thorough examination of the decision taken.

\section{RESEARCH METHOD}

This research occurred in three phases and was used to analyse the effectiveness of using the pedagogical documentation strategy and using kahoot application for assesment.

\section{Phase 1}

This involved using kahoot application to get assesment before the class begin. Student at M-1 answer the 5 question using kahoot application.

\section{Phase 2}

Students in this phase began to learn about biotechnology and using teachear give a problem about biotechnology. Problem based learning using for increase student critical learning.

\section{Phase 3}

Students began to uses some assessment tools they had developed collaboratively by which they were able to assess their work. First, student make group and every group have a different question with a same level. Second, posttest for all student using kahoot application. Data collection was performed through pretest and posttes. The questions used in pretest and posttest critical thinking questions according to Ennis with dimensions; 1) provide a simple explanation (Basic Clarification), 2) build basic skills (Basic Support), 3) inference, 4) provide further explanation, 5) organize strategies and techniques.

Population is a generalization region consisting of objects/subjects that have certain qualities and characteristics set by researchers to be studied and then drawn conclusions (Sugiyono, 2011). The population in this study were all students of class M1/4 at Hatyaiwittayalai somboonkulkanya school which amounted to 45 students.

The variables in this study consist of dependent variable and independent variable. The dependent variable in this research is critical thinking of student. The independent variable in this study is the science learning of material changes in the properties of objects by using problem based learnin. 


\section{RESULT AND DISCUSSION}

The purpose of this study was to determine the problem based learning model for increasing the critical thinking skills for M-1 students in Hatyai wittayalai somboonkulkanya School. Ability to think hard for tests. The first test is a test in the form of pretest and posttest students. The postest results compared with the results of the pretest show that happened increased critical thinking. Pretest average value in this study was 27 while the value the average posttest is 36,9 .

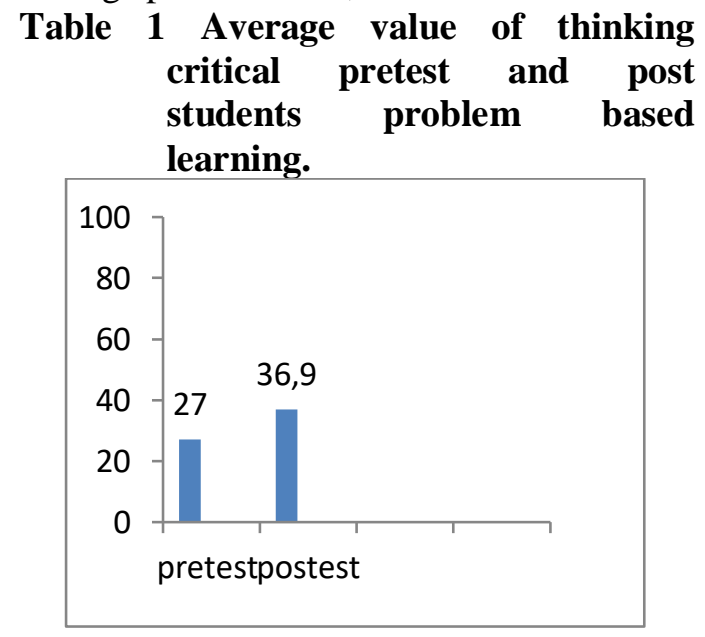

Based on the table, the improvement of students critical thinking skills. In the table above shows that the average increase in students critical thinking skills. Although the n-gain criteria themselves are both in the medium category, in the experimental class there are some students who have high n-gain values, whereas in the control class there are no high criteria. This shows an increase in students critical thinking skills in the experimental class using a problem based learning with kahoot aplication higher than the control class using conventional learning with problem based learning model.

Based on the results obtained, it can be seen that in the experimental class the students critical thinking abilities experienced a higher increase than the control class after being treated in the form of teaching and learning using a problembased learning model assisted by computer media. The most significant increase based on indicators of critical thinking measured is when students analyze questions and ask questions and answer questions about an explanation or statement, while to focus the question is still lacking. This is different from the control class which only experienced a slight increase from the indicators of critical thinking measured.

The results above occur because in the experimental class a teaching is carried out by making students the main role in a teaching and learning process, where students will be more active in learning and solving the problem and the teacher is only a facilitator. Using computer media in the form of pictures and videos makes the teaching and learning process in the classroom more active and enjoyable so students will more easily understand the material being taught. When learning takes place, students are more likely to work on problems given by the teacher. When students are given a even some of the students force themselves to solve the problem given. This shows that students are more enthusiastic and more active in the teaching and learning process, so that the pure learning process is focused on students. In addition, in the teaching and learning process conducted in this class also uses a group work system to solve problems by the teacher and arranged in the form of student worksheets. This is done so that there is interaction between students which later will make students exchange opinions and thoughts to get the best solution in solving the given problem, then the thoughts of the group are assembled together and presented in front of the class. After the group representatives explained the results of their group's work, other groups were given the opportunity to ask or respond to it, so that there was interaction between students in one class. This is what makes students absorb the subject matter more quickly. Students who were passive in learning by applying this learning model, students become excited and focus more on learning. The results of this study are in line with the research.

Based on all the data that has been described, it can be concluded that, there is an effect of problem-based learning model

Bioedukasi Vol. XVII. No. 1 April 2019 
on the critical thinking skills of M-1 students in Hatyaiwittayalai somboonkulkanya school. Increased critical thinking skills occur because during the learning process students are required to solve the given problem and then explain it according to the concept. The advantage of this learning model compared to conventional learning is student activity. Through this learning model students are involved to actively think and find directly the meaning or concept they want to know.

The shortcomings in this learning model is that the teacher must patiently guide students to find their own understanding or concept of the material they want to know. In addition, another disadvantage in using this learning model is that teachers rely on electricity in using the media, because they use computers / laptops. If the character of students in the classroom enjoy playing games, then use a fun learning model for them so that students can better understand and be active in the teaching and learning process. Problembased learning in its implementation requires quite a lot of preparation, researchers should be able to calculate the time in each phase of learning to be more efficient, because time is one of the obstacles in the learning process. The implementation of this learning model also depends on the internet to carry out the pretest and posttest. The implementation of this learning model that is supported by the kahoot application is recommended for schools that have adequate facilities. Difficulties experienced are the ability of English students. Student have different english ability. So student have low result.

\section{CONCLUSION}

Based on the results it can be concluded that students' critical thinking abilities who were treated with problembased learning were higher than students who received conventional learning in the M-1 class at Hatyai Somboonkulkanya school. Based on the conclusion there are some suggestions that can be put forward. The use of learning models, the most important thing that must be considered is the character of students. If the character of students in the classroom tends to enjoy playing, then use a fun learning model for them so that students can better understand and be active in the teaching and learning process. (2) Problem-based learning model with the help of computer media in its implementation requires quite a long time and sufficient preparation, researchers should be able to take into account the time in each phase of learning to be more efficient, because time is one of the obstacles in the learning process

\section{ACKNOWLEDGEMENT}

With all respect and humility, the team of writers praise the presence of Allah Almighty for all His grace, so that the writers can finish this article. In making this article, the author's team gained valuable guidance, assistance, and guidance from various parties. On this occasion, the team of authors would like to extend their gratitude to Erlia Narulita, S.Pd.,M.Si., Ph.D, Official of UPPL FKIP Universitas Jember and YORSOR school where this research was conducted, who have taken the time and opportunity to give opportunity, direction, and guidance in completion of this article.

\section{REFERENCE}

Barber, Wendy, Sherry King \& Sylvia Buchanan. 2015. Problem Based Learnig and authentic assessment in digital pedagogy: Embracing the role of collaborative communities. The Electronic Journal of e-learning. 13 (2).

Dewanto W. K. 2018. Developing thingking skill system for modelling creative thingking and critical thingking of vacational high school student. Journal of Physics. 953.

Diasputri A, Sri.N, Warlan S. 2013. Pengaruh Model Pembelajaran Probing Promting Berbantuan Lembar kerja Berstruktur Terhadap 
Hasil Belajar. Jurnal Inovasi Pendidikan Kimia. 7(1).

Ennis, Robert. 1991. Critical Thinking: A Streamlined Conception. University of Illinios: Artikel Teaching Philosophy.

Ersoy, E. \& N. Baser. 2014. The effect of problem based learning method in Higher education on creative thingking. Procedia-social Behavir Science. 116.

Hadi, S. A., E. Susandti \& R. Agustini. 2018. Trainimg of student critical thinking skills through the implementation of a modified free inquiry model. Journal of Physics. 1.

Hidayat, Agus S., Ramdhan Witarsa, Rian Hadiansah \& Rini Sriwahyuni. 2018. Children learning in science on improvement of learning results in SDN 1 Sudimampir. Journal of elementary education. 1(1).

Megasari, Agus Sudaryono \& M. Lutfi Firdaus. 2018. Pembelajaran probing prompting untuk meningkatkan berpikir kritis siswa anggota kelompok ilmiah remaja. Pendipa Journal of Science Education. 2(2).

Naimnule, Lusia \& Aloysius Duran Corebima. 2018. The correlation between metacognive skills and critical thinking skills toward student process skills in biology learning. Journal of Pedagogical Research. 2(2).

Savin-Baden, Maggi. 2007. Challenging models and perspective of problem based learning. London: Cassell.

Setiawan, A., A. Malik \& A. Permanasari. 2018. Effect of Higher Order thingking laboratory on improvement of critical and creative thingking skills. Materials Science an Engineering. 306.
Sugiyono. 2011. Metode Penelitian Kombinasi (Mixed Methods). Bandung: Alfabeta.

Sutarma I N, Arnyana I B P \& Swasta I B J. 2014. Effect of inquiry learning model on critical thinking skills and scientific performance on biology lesson of class xi ipa sma negeri 2 amlapur. e-Journal Program Pascasarjana Ubiversitas Pendidikan Ganesha. 4.

Bioedukasi Vol. XVII. No. 1 April 2019 